\title{
ТРАНСДИСЦИПЛІНАРНА ІНТЕЛЕКТУАЛЬНА ІНФОРМАЦІНО-АНАЛІТИЧНА СИСТЕМА СУПРОВОДЖЕННЯ ПРОЦЕСІВ РЕАБІЛІТАЦІЇ ПРИ ПАНДЕМІЇ (ТІSР)
}

\author{
Палагін О. В.
}

\author{
Інститут кібернетики імені В.М. Глушкова НАН України, м. Київ, Україна \\ https://orcid.org/0000-0003-3223-1391
}

\begin{abstract}
Для кореспонденції: Палагін Олександр Васильович, доктор технічних наук, професор, академік Національної академії наук України, заступник директора Інституту кібернетики з наукової роботи, проспект Академіка Глушкова, 40, м. Київ, 03187, Україна; фракс: (044) 526-33-48; e-mail: palagin_a@ukr.net; контактний тел.: +38 (067) 2869796.
\end{abstract}

Сучасний розвиток інформаційних технологій дозволяє вирішувати проблеми великої і надвеликої складності. Їх застосування в різних напрямках забезпечення національної безпеки дає позитивні результати. Сьогодні існує нагальна потреба підтримати розвиток нової в Україні медичної галузі - Фізичної та Реабілітаційної медицини. Створена в Інституті кібернетики Базова когнітивна інформаційна технологія стала основою для розробки Трансдисциплінарної інтелектуальної інформаційноаналітичної система супроводження процесів реабілітації.

Мета дослідження - це створення Трансдисциплінарної інтелектуальної інформаційно-аналітичної система супроводження процесів реабілітації при пандемії (TISP).

Для побудови TISP була використана базова когнітивна інформаційна технологія (БКІT), що створена в Інституті кібернетики HАН України і постійно розвивається. За допомогою методів проблемної орієнтації створена архітектура TISP, що задовольняє потреби спеціалістів з фізичної та реабілітаційної медицини.

В результаті побудовано інформаційно-аналітичну систему у вигляді сукупності функціональних підсистем, які підтримують всі етапи життєвого циклу від постановки діагнозу до оцінки ефективності процесу реабілітації.

Функціональне наповнення системи спирається на методологічні засади відновлення та реабілітації у відповідності 3 рекомендаціями Білої Книги з Фізичної та Реабілітаційної Медицини та Міжнародною Класифікацією Функціональностей, які $€$ ключовими Європейськими матеріалами, відомими спеціалістам усіх рангів: від практикуючих лікарів до осіб, що приймають рішення на державному рівні в галузі охорони здоров'я. I це цілком обгрунтовано: вони орієнтуються на людину в суспільному житті, а не на окремі іï захворювання.

Вперше в Україні в резудьтаті інтенсивної взаємодії кібернетиків і професіанальних лікарів-реабілітологів створено інтелектуальну інформаційно-аналітичну систему супроводження процесів реабілітації при пандемії.

Ключові слова: когнітивна інтелектуальна технологія, трансдисциплінарні наукові дослідження, онтологічний інжиніринг, ноосферна теорія, дослідне проєктування, Міжнародна класифікаиія функиіональностей.

Вступ. Фізична та медична реабілітація $\epsilon$ первинною медичною спеціальністю на усій території Євросоюзу, а Міжнародна класифікація функціонування, обмежень життєдіяльності та здоров'я (МКФ) є головним інструментом оцінювання ефективності реабілітації і організації реабілітаційної допомоги. Тому прийнятий 03.12.2020 р. Закон України «Про реабілітацію в сфері охорони здоров'я» забезпечив стрімкий розвиток фізичної і реабілітаційної медицини в Україні. Створена у відповідності 3 проєктом Національного Фонду Досліджень України система під назвою «Трансдисциплінарна інтелектуальна інформаційно-аналітична система супроводження процесів реабілітації при пандемії (TISP)» $\epsilon$ результатом плідної роботи команди професіоналів з інформатики і реабілітаційної медицини та певним внеском в розвиток цієї важливої для України галузі.

Головний акцент в роботі був направлений на створення інтелектуальної інформаційної технології, яка підтримує процес реабілітації на всіх етапах життєвого циклу, від постановки діагнозу i формування реабілітаційного маршруту до його реалізації і оцінки ефективності реабілітаційного процесу. Крім того система має певні функціональні можливості підтримки науково-дослідних робіт в названій галузі й прийняття рішень на рівні керування цією галуззю, а також в навчальноучбового процесі. Відмінною особливістю TISP $\epsilon$ те, що вона побудована на фундаменті вже достатньо відпрацьованої авторським колективом Базової когнітивно-інформаційної технології (БКІТ), яка здатна розвиватися як функціонально, так і архітектурно у відповідності до концепції систем дослідного проєктування, де остання виступає одночасно як об'єктом, так і інструментом проєктувального процесу. Штучний інтелект в TISP представлений функціями обробки природномовних текстів i видобування знань, які потім перетворюються системою із пасивної форми в активну (інтерактивну).

Що стосується терміну «трансдисциплінарний», то він апелює перш за все до основних парадигм розвитку наукових знань, в більш загальному плані - до Глобальної еволюційної теорії, а саме - Ноосферної теорії академіка В. І. Вернадського 
(до речі, засновника Національної Академії Наук України).

\section{Концептуальні основи розробки системи.}

Побудова еволюційних теорій протягом всього періоду усвідомленого існування людської цивілізації, була предметом інтенсивних досліджень вчених [1,2]. Ноосферна теорія Вернадського про перетворення біосфери в ноосферу в ході глобальної еволюції планети Земля під дією наукової думки була і залишається геніальним досягненням природничих і соціогуманітарних наук $[1,3]$. Ця теорія поставила Людину, як носія наукової думки, відповідальним за прийняття рішень в усіх сферах соціоприродного процесу з позиції перспективності розвитку людської цивілізації. Цей процес іде шляхом від простого до складного i людина, як складова біосфери, підкорюється цьому закону. Головний критерій досягнення цілі - гармонійна єдність в системі «Людина - Природа».

Ключові ознаки ноосферогенезу стосуються розвитку базових складових розвитку сучасного суспільства (задоволення фізичних, духовних, матеріальних потреб людини, ефективна наука, нова енергетика, інформаційно-комунікаційні технології оптимізація міжлюдської взаємодії, космічна сфера). Основним методологічним принципом по Вернадському повинен стати синтез наукових ідей («ми спеціалізуємося не на науках, а по проблемах»).

В цьому плані важливим розділом знань виступає теорія дисциплінарності (ТД), що формується сьогодні на правах науки. Вона визначає новий науковий світогляд $\mathrm{i}$ підхід до постановки i розв'язанню складних наукових i практичних проблем у їх взаємозв'язку на засадах єдиного погляду на явища навколишнього світу 3 позиції $\mathrm{i}$ вимог керованих еволюційних процесів, включаючи антропогенну складову [4]. При цьому складність проблем, що виникають перед наукою в сучасному світі, обумовила необхідність нової, більш складної і більш ефективної моделі науки, що усувала б нічим не виправдану відособленість окремих дисциплін.

ТД може забезпечити розв'язання центральної проблеми керованої еволюції (за Вернадським ноосферогенезу) - побудови Наукової картини cвimy та на ïi основі Сдиного закону природи. На цьому шляху найяскравішим стало явище (закон) конвергениії та кластеризації окремих дисциплін i відповідних їм технологій. Найбільш відомим (насправді не єдиним) виявився NBIC-кластер (нано-біо-інформаційно-когнітивні технологіï), що з)явився у 2000-ні роки і забезпечив розробку нових перспективних засобів в різних галузях, зокрема в медицині (біопротези, штучні органи тощо)

Одним 3 найбільш важливих розділів ТД-теорії є системологія ТД-взаємодї, задача якої полягає у методичній та когнітологічній підтримці формування нових наукових знань. Кінцевою метою застосування методів і засобів системологічної підтримки процесу інтеграції наукових знань $є$ створення Єдиного інтегрованого ТД-знання.

Головний постулат трансдисииплінарності: знання законів природи єдине і неподільне.

Когнітивна еволюція є складовою частиною глобальної еволюції. Вона включає два розділи. Перший 3 них пов'язаний 3 еволюцією механізму людського мислення з поступовим закріпленням на генетичному рівні домінування логіко-вербального типу над просторово-образним, що в кінцевому рахунку відбивається на особливості сприйняття людиною навколишнього світу, культурі, активної діяльності, зокрема підтримці здоров'я. Другий розділ стосується вдосконалення інформаційнокомунікативних технологій та інформаційного забезпечення. Обидва розділи розкривають суть поняття інфосфери, запропонованого В. І. Вернадським.

Запропоновано [1] модель цілеспрямованого формування суспільної свідомості, яка заснована на мовній картині світу (МКС). 3 різними варіаціями когнітивний цикл можна уявити у вигляді послідовності взаємопов'язаних когнітивних актів. Акт розуміння реалізується шляхом порівняння нових знань зі старими через категорію сенсу [5]. Він являє собою спосіб функціонування свідомості. Остання має мовний статус. Ці знання зафіксовані в формованій в свідомості суб'єкта мовній картині світу (МКС), що $є$ варіантом деякої понятійної структурної класифікації об'єктів реального світу. Дуже важливим є узгодження інтересів суб'єкта i суспільства, з орієнтацією на глобальну стратегію еволюції.

Передовий досвід і загальний аналіз рекомендують при цьому ряд перспективних ініціатив:

1) акцент у вихованні «високої» свідомості на розвитку культури (мистецтва),

2) створення Інституту людини для дослідження проблем еволюційного розвитку людини i суспільства,

3) розширення ігрових стратегій роботи з масовим учасником в режимі crowdsourcing,

4) застосування формальних математичних методів вирішення конфліктів,

5) використання систем із зворотним зв 'язком (33) з високим рівнем штучного інтелекту (в медицині системи з біологічним 33).

При цьому для суб'єкта важливим є знання базових законів еволюції:

а) у відношенні до загальної біосфери,

б) у відношенні до свого організму.

Зрозуміло, що б) $є$ складовою а) i що обов' язковими умовами гармонійної єдності в системі «Людина - Природа» є підтримка здоров'я нації в широкому сенсі. Поняття «здоров'я» спирається на формалізовану модель здоров'я людини, побудовану на базі сучасних медико-біологічних теорій та методів онтологічного інжинірінгу з використанням експериментального моделювання на основі метода Делфі. 
В комп'ютерній онтології $O=\langle X, R, F\rangle, X$, $R, F-$ відповідно множини понять, відношень та визначень.

Фундаментом загальної концепиії здоров'я є три рівня їх забезпечення:

1) підтримка і профілактика,

2) лікування хвороб,

3) реабілітація.

Всі три рівня можуть і повинні використовувати методи самовідновлення. Останні так чи інакше відносять до інтегративної медицини (IM) [6]. Цим терміном часто користуються замінюючи ним термін нетрадиційна (альтернативна, неформальна). В більшості випадків мова йде про поєднання методів традиційної і нетрадиційної медицини. Прийнято вважати, що вона не має наукової доказової основи. Тим не менше, деякі види IMтерапії пропонуються в клініках і відшкодовуються страховими компаніями, а в ряді медичних учбових закладів (особливо в США) дають освіту в області IM. C точки зору трансдисциплінарної парадигми інтегративна медицина, особливо реабілітаційна, демонструє приклад еволюційного розвитку, а пошук ефективних кластерів конвергенції методів і засобів IM аналогічних NBIC (див. вище) $\epsilon$ актуальною задачею сучасної медицини (як науки, так і медичної технологіï).

Використання тисячорічного досвіду східної медицини у поєднанні із сучасними методами нейрокомунікативного та інформаційного супроводження 3 використанням систем штучного інтелекту, енергетичні, гомеопатичні, натуропатичні, акупунктурні, його-дихальні, арт-музичні та інші відомі техніки поряд 3 традиційними методиками лікування, сучасними засобами моніторингу i корекції стану пацієнта $\epsilon$ надійним шляхом підвищення ефективності сучасної медицини i забезпечення здоров'я нації. На фоні інших підкреслимо перспективи розвитку методів і засобів біологічного зворотного зв'язку (Б33), який використовує сучасні досягнення нейропсихології і інформатики. В зв'язку з тим, що БЗ3 є різновидом інтерактивних систем (IC) актуальними стають такі нові технології, як crowdsourcing, багатоагентні IC (Б33), створення консолідованого (штучного $\&$ природного) інтелекту, оріснтовані на функції відновлення організму i реабілітації. При цьому досліджується тріада: знання - розуміння (знань) втручання $з$ оцінкою засвоєних знань у форматі так званих нечітких знань (fuzzy knowledge), маючи на увазі ітераційний процес:

$K^{f}+(\Delta K)_{i}=K^{0}, i=1,2, \ldots \quad$ з використанням метричної системи Раша, інтервальних шкал, оцінок латентних властивостей особи, критеріїв валідності тощо. Названі методи однаково цікаві і корисні як для відпрацювання ефективних технологій реабілітації, так і для розвитку напряму штучного інтелекту.

Базова когнітивна інтелектуальна технологія

B основу розробки TISP покладено базову когнітивну інтелектуальну технологію БКІТ), розроблену колективом авторів в попередні роки [7]. Вона $є$ основою побудови як інформаційноаналітичної системи, так і системи, що підтримує процес іï проєктування (дослідного проєктування, підкреслюючиприцьомунауково-досліднускладову). БКІТ обслуговує повномасштабний процес збору, аналізу великих обсягів інформаційних матеріалів, формалізованого їх представлення, формування систем предметних знань та їх системну інтеграцію у відповідності з концепцією трансдисциплінарності, управління процесами, розробки сервісів та підтримки прийняття оптимальних рішень, розвитку системи як такої.

Основою роботи системи є знання-орієнтовані алгоритми i технології, що підтримуються 3 боку БКІТ. В системі знання грають дві ролі: 1) системного інтегратора архітектури і 2) кінцевого продукту, у вигляді сервісів, методик, засобів тощо. У зв'язку 3 цим важливим $є$ поняття уніфікованих явних конструктивних знань, що можуть бути безпосередньо використані в практиці. Звідси вимога наявності єдиного стандарту електронного представлення знань. В цьому плані доречно згадати про поданий вище формалізм комп'ютерних онтологій, що де факто виконує роль такого стандарту на рівні специфікації і частково концептуалізації знань. Життєвий цикл знань починається збором і систематизацією релевантної інформації, перетворенням iї в пасивну, а потім в активну (системну) форму знань, що виконується у фазі науково-дослідної роботи з використанням моделювання, обробки математичними методами, оптимізації. Насамкінець отримується електронне (сервісне) представлення знань 3 інтелектуальними функціями інтерфейсу і їх супроводження. Доречі, онтологічна модель $€$ декларативним представленням знань. В [4] запропоновано клас понятійно-образних онтологій, який розширює можливості методів онтологічного інжинірінгу, зокрема в задачах розпізнавання графічних образів (когнітивна графіка), геоінформаційних застосувань тощо.

В основі системи дослідного проєктування лежить технологія системної інтеграиії методів, інструментальних засобів і формалізованих процедур: побудова об'єктів високого рівня із компонентів низького рівня, систематизація типових проєктних рішень, реконфігурація архітектури системи.

Сама БКІТ реалізована у вигляді платформи, доступної користувачеві в Інтернет-середовищі незалежно від точки доступу, і функціонує на основі глибокого семантичного аналізу інформаційних матеріалів, представлених у вигляді природномовних текстів 3 процедурами самонавчання, синтезу, формалізаціїі інтерактивної взаємодіїз користувачем. До iї складу входять такі підсистеми (ПС): контекстного синтактико-семантичного аналізу природномовних текстів (КССА), побудови онтології предметної галузі (ПОПГ), редактора онтологій (РО), 
пошуку і індексації вхідних даних (IВД), розв'язання аналітичних задач (РАЗ), відображення об’єктів і процесів (ВОП). Головною особливістю БКІТ $\epsilon$ підтримка цілеспрямованого діалогу з користувачем на базі елементів консолідованого (штучного i природного) інтелекту.

Опис системи TISP та ії̈ складових.

У відповідності до планових завдань проєкту було виконано комплекс робіт з проблемної орієнтації БКІТ [8]. В нього ввійшли: на першому етапі розробка стратегії розширення функціональності БКІТ, на другому - розробка функціональних підсистем реабілітаційного профілю, а саме:

- підсистема аналізу вихідних даних в галузі Фізичної та Реабілітаційної медицини (ФРМ) (на базі підсистеми індексації),

- підсистема Міжнародної Класифікації Функціональностей (МКФ),

- онтологічна підсистема супроводження Білої книги ФРМ (БК ФРМ),

- підсистема розробки і супроводження методології реабілітаційних заходів в умовах пандемії (МР3),

- підсистема розробки, корекції і супроводження реабілітаційних заходів (РР3),

- підсистема оцінки ефективності реабілітаційних заходів (ОЕРЗ),

- підсистема інформаційно-аналітичної підтримки комплексу діагностичних процедур (ПКДП),

- підсистема моделювання здоров'я людини та інші (МЗЛ).

TISP як повну систему можна представити у вигляді наступної функціональної схеми, де: БК - базова конфігурація, ФПР - функціональні підсистеми реабілітації.

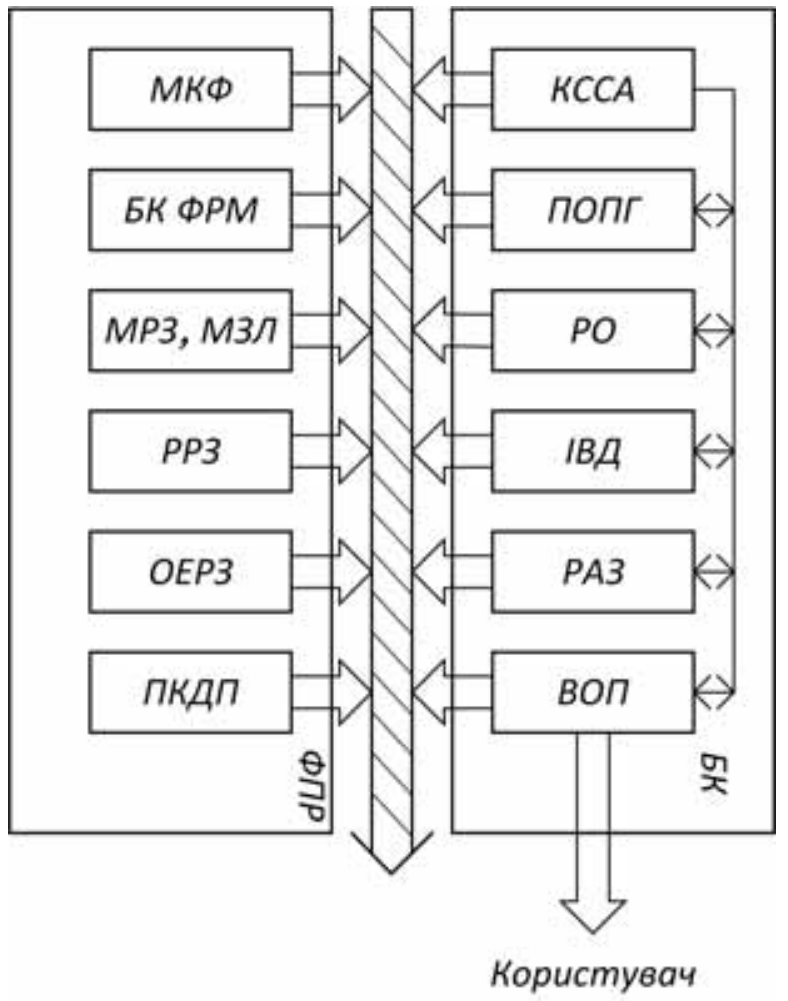

Таким чином на рівні БК вирішуються задачі: опису предметних галузей і процесів в онтологічній формі, структуризації i трансдисциплінарної інтеграції великих масивів даних (автоматичне виділення контекстів, семантичних відношень), формування спеціалізованих користувацьких інтерфейсів для відображення інформації в зручній для сприйняття формі, підтримки прийняття рішень, формування узагальнених описів класів об'єктів на основі навчання , класифікації об'єктів, прогнозування властивостей об'єктів і процесів. Система працює в англійській і українській мовах.

На рівні ФП вирішуються задачі обслуговування процесів реабілітаційної медицини, пов'язаних перш за все з взаємодією на рівні доктор - пацієнт. Ця взаємодія і підсистема РРЗ реалізуються на базі кабінету супроводження реабілітаційних заходів. Останній складається 3 трьох функціональних модулів: адміністрування бази пацієнтів, створення і виконання медичних тестів, оцінки пацієнтів за МКФ. Підсистема забезпечує процес керування наявними в системі лікарями і пацієнтами. Кожен лікар може входити в систему за своїми «логін» i «пароль» і виконувати всі доступні йому дії. Керування пацієнтами виконується за допомогою набору ієрархічних форм. Список пацієнтів дозволяє робити вибір простим натиском на його ім'я в екранному вікні. Всі обстеження містять дату, тип і список лікарів, хто приймає участь. Основою тестів $є$ дерево запитів. Кожна відповідь складається 3 трьох частин - текстової, числового значення і опису. Вони використовуються модулем оцінок. Модуль оцінок доступний в бібліотеці додатків. Пункт «вибір медичних тестів» дозволяє вибрати ті тести, які потрібні спеціалісту і виконати оцінку за ними. Виконання тестів полягає у виборі відповідей із списків, що випадають. Аналогічно працює оцінка за МКФ. Вибрані домени МКФ відображаються у функціональному полі «Виставлення оцінок МКФ», де лікар може виставити оцінки за сконфігурованими для кожного 3 доменів шкалами. На основі виставлених оцінок формується профіль.

Підсистема оиінки ефективності реабілітаційних заходів (ОЕРЗ) обслуговує сервіс оцінки на основі МКФ профілей пацієнтів i дозволяє проводити комплексну аналітику процесу їх відновлення, a саме:

- визначати реабілітаційний потенціал пацієнта 3 метою оцінки можливостей до відновлення,

- встановити інтегральний реабілітаційний показник після курсу реабілітації, що дозволяе визначити ступень відновлення компенсаторних можливостей,

- аналізувати динаміку зміни оцінок по МКФ та виявити найбільш проблемні фактори.

Підсистема, крім безпосереднього оцінювання по шкалам, працює 3 анкетами та картками пацієнтів певного формату. Окремий програмний модуль реалізує відповідну методику оцінювання, 
яка шляхом вимірювання показників порушення функцій організму, активності i участі виконує оцінку ефективності реабілітаційних заходів. Реабілітаційний потенціал нормалізується у шкалу від 0 до 1, що дозволяє отримувати єдине значення незалежно від кількості шкал. Якість реабілітації вимірюється у відсотковій шкалі та має лінгвістичну градацію виду: «бездинаміки», «задовільно», «добре», «дуже добре». Таким чином можна формалізувати задачу обчислення значень показників верхніх рівнів, як деяких функцій над числовими значеннями. На практиці існують і обернені задачі, коли треба знайти показники нижнього рівня, які найбільш негативно впливають на показники верхніх рівнів. Розв'язок цієї задачі дозволяє визначити оптимальну стратегію реабілітації пацієнта. Користувацький інтерфейс підсистеми виконано на базі графічної візуалізації. Багаторівнева архітектура підсистеми ОЕР3 дозволяє інтегрувати нові технології та долучати нові компоненти без перепроєктування всього програмного забезпечення.

Підсистема інформаційно-аналітичної підтримки комплексу діагностичних процедур виконує функції оцінки клінічного стану пацієнта, факторів ризику проведення реабілітаційних заходів, факторів, що обмежують їх проведення, морфологічних параметрів, функціональних резервів організму, стану вищих психічних функцій, порушення побутових та професійних звичок.

Зроблено акцент на діагностичні засоби телереабілітаціï, що обумовлено сьогоднішніми вимогами безпеки в період пандемії. На першому плані в підсистемі виявились методи контролю кардіологічних та психофізіологічних показників, а також системи з біологічним зворотнім зв'язком.

Виконано орієнтацію на технологію реабілітаційного телемоніторингу, як правило в домашніх умовах пацієнтів. Зазвичай такі системи включають датчик (в кардіологічному моніторингу це мініатюрний ЕКГ-прилад, можливо з пластирем 3 одночасним вимірюванням кров'яного тиску), модуль зберігання та транспорту даних, сховище даних, інтерфейс діагностики за правилами когнітивної графіки. В проєкті використовується оригінальне сертифіковане програмне забезпечення.

Накоплено досвід використання даного комплексу в процесі психологічної реабілітації пацієнтів 3 посттравматичними стресовими розладами як в цивільному, так i військовому застосуваннях. За часи пандемії COVID-19 проблема виникнення психологічних розладів стала ще більш актуальною. Апробація на пацієнтах виявила позитивні результати використання даного комплексу. За допомогою даної технології лікар може оцінити ефективність та своєчасність виконання поставлених задач, корегувати методику тощо. Між сеансами зустрічей пацієнт може самостійно оцінювати свій стан.

Системи з біологічним зворотнім зв'язком та інші вирішено будувати на основі численних оригінальних розробок Інституту кібернетики (і його партнерів), в яких приймали участь члени авторського колективу. Одна 3 таких розробок - програмно-апаратний комплекси (ПАК) «Психолот», призначений для реєстрації психологічного та психофізичного стану пацієнтів та оцінки ефективності реабілітаційних процедур. Програмне забезпечення дозволяє вести базу даних пацієнтів, виводити на екран тести, реєструвати помилки та швидкість реакції, обчислювати інтегральний критерій та генерувати звіти. В комплексі 3 Б33 «Психолот» повинен виконувати режим тренажера. При цьому несвідомо покращуються психомоторні навики, когнітивні функції та ін. Ці показники, виведені на екран, дозволяють пацієнтові слідкувати за процесами i намагатись покращити результати, тобто маємо певний різновид зворотнього зв'язку. При цьому можлива його додаткова стимуляція (звукова, теплова, електромагнітна тощо).

Підсистема телемедичного супроводження реабілітаційних заходів виконана як окрема Smartсистема i призначена для надання реабілітаційних послуг пацієнтові в дистанційному режимі. Сенс цього напряму реабілітації у тому, що пацієнт самостійно, як правило у домашніх умовах, виконує програми відновленого лікування на амбулаторному етапі під дистанційним контролем спеціаліста. Основними завданнями дистанційно-контрольованої реабілітації $є$ оцінка іï клінічної ефективності за ступенем відновлення функцій, виявленням ускладнень, встановлення оптимальної тривалості курсу занять. С можливість працювати в форматі міждисциплінарної реабілітаційної команди на рівні установи (телереабілітаційного центру). Всі процедури, включаючи оцінку реабілітаційного потенціалу, виконуються 3 використанням Міжнародної класифікації функціональностей та оціночних шкал. Основним критерієм включення пацієнта в програму реабілітації $є$ наявність Інтернету, веб-камери, організації робочого місця. На теперішньому етапі розробки Smart система TP (без термінальної частини) включає ряд різноманітних технологій, сервісів та інструментів, зокрема:

- сервіc UkrVectōrēs для дослідження, вивчення предметної галузі, що працює на основі семантичного аналізу природної мови, діагностики та класифікації, та

- сервіс «Електронна бібліотека vHealth» розподілена інформаційна система, що дозволяє зберігати, розповсюджувати та використовувати різнорідні колекції електронних документів (відеота аудіоконтент), орієнтованих на дистанційне навчання пацієнтів та їх родичів.

Перший сервіс - це інструмент дистрибутивного аналізу природної мови, окремих контексних сутностей тексту. Користувач може вибрати одну або кілька прогностичних моделей, навчених на різних корпусах текстів (зокрема «Біла Книга з Фізичної та Реабілітаційної медицини в Свропі». Виконуються 
алгебраїчні операції над векторами слів для того, щоб отримати певний вектор з масиву чисел (слів) та його візуалізацію, наприклад для пошуку необхідних інформаційних об'єктів. На теперішній час актуальна версія UkrVectōrēs доступна при зверненні до Інституту кібернетики.

Другий сервіс - це електронна бібліотека медіа файлів підсистеми телереабілітації, що представляє собою розподілену інформаційну систему, щоб використовувати та розповсюджувати (функція шерингу)різнорідніколекціїелектронних документів, зокрема відео- та аудіоконтент) для дистанційного навчання пацієнтів. Одним з основних завдань сервісу «vHealth» $\epsilon$ ефективна навігація на інтегрованому інформаційному ресурсі з метою пошуку необхідного медіа-контенту при мінімальних зусиллях. Розвинуті функції розширеного адміністрування та соціальномережеві функції, маніпулювання зі структурою опису об'єкту, підтримки багатомовних файлів субтитрів для відеоконтенту.

Насамкінець, відмітимо, що увесь реабілітаційний процес, який підтримано системою TISP, базується на комп'ютерній версії Міжнародної класифікації функціональностей, що реалізована в окремій підсистемі та багатофункціональному представленні Білої Книги 3 діалоговими функціями. Останні базуються на використанні графової бази даних та клієнт-серверної архітектури. Природомовні способи людино-машинної взаємодії - дуже перспективний сервіс тому, що $є$ зручним і інтуїтивно зрозумілим.

Метод семантичного аналізу i побудова на його основі формальних запитів і відповідей дає можливість обслуговувати широкий клас користувачів (лікарів, науковців, пацієнтів). Цей сервіс надає можливість створення так званих ботів - віртуальних користувачів, що можуть бути підключеними до зовнішнього сервісу, що отримує повідомлення і надсилає свої. Сервіс обслуговується інтерфейсом у вигляді вікна, здатного згортатися i розгортатися і має вигляд веб-сторінки. Користувач може надсилати свої запитання, навіть не чекаючи відповіді. Всі вони будуть оброблені, а відповіді дані по мірі отримання.

Вище були описані основні функціональності системи TISP та їі підсистеми.

Дискусія і висновок. В ході виконання проєкту були виявлені деякі проблеми, вирішення яких дозволить підвищити рівень і ефективність реабілітаційної технології.

Перша з них пов'язана зі створенням єдиного підходу до вибору оціночних шкал для діагностики на різних етапах реабілітації із застосуванням МКФ [9]. Більш конкретно, можна запропонувати створення комп'ютерної реалізації матриці суміжності \| D $\mathrm{S}\|\|^{\mathrm{ij}}$ (домен - шкала) $i=1,2 \ldots \quad m ; j=1,2, \ldots n$. Клітини матриці, в якій співпрацюють $i$-й елемент МКФ і j-та шкала, містять «1» (одиницю), всі інші - «0». Обслуговування операцій цією матрицею у зв'язку з іiі великою розмірністю потребує структуризації матриці і управління всіма процесами. До даної проблеми відноситься i необхідність створення окремої матричної структури для систем телереабілітації в зв'язку з їх особливостями.

Друге проблемне питання відноситься до розвитку систем з біологічним зворотнім зв'язком. Його вирішення лежить у сфері штучного інтелекту і стосується інтелектуалізації методів та засобів інтерпретації фізіологічних показників у зорові образи, які стимулюють відновлення організму пацієнта за рахунок саморегуляції. В загальному плані проблема торкається розробки знання-орієнтованих підходів до створення систем консолідованого інтелекту (див. вище).

В цілому можна констатувати, що вперше в Україні створено систему інтелектуально-технологічної підтримки в галузі Фізичної та Реабілітаційної медицини. Розроблена система (TISP) може використовуватись не тільки в безпосередньому супроводженні реабілітаційних процедур на рівні «лікар - пацієнт, але і в якості системи підтримки прийняття рішень на різних рівнях, а також навчальних і дослідних процесів.

Додаткова інформація. Опубліковані матеріали не мають конфлікту інтересів.

Подяка. Дослідження виконано за фінансовою підтримкою Начіонального Фонду Досліджень України (договір № 159/01/245 від 07.05.2021p.

\section{Література}

1. Загородний А.Г., Волков С.В. Онищенко О.С., Шестопалов В.М. В.І.Вернадський - вчений, мислитель, організатор науки. Вісник Національної академії наук України. 2013. №32. С. 8-37.

2. Палагин А.В. Информационно-технологические средства управляемой эволюции. Проблемы управления и информатики. 2021. №5. C.104-123. DOI: 10. 34 229/1028-0979-2021-5-9.

3. Palagin AV, Kyrgaev AF, Shevchenko AI. Noosphere Paradigm of the Development of the Science and Artificial Intelligence. Cybernetics and System Analysis. 2017; 5 (53): 503 - 511. Doi: $10.1007 / \mathrm{s} 10559$ - 017 - 9952 -

4. Palagin AV. An Introduction to the Class of the Transdisciplinary Ontology - controlled Research Design Systems. USIM. 2016; (6): 3-15. Doi: 10.15407

5. Palagin AV. Arrangement and functions of a Language world picture in semantical interpretation of natural language messages. Informational theories \& applications. 2000; 7 (4): 155-163.

6. Finnis G, Kaptchuk TJ, Miller F, et al: Placebo effects: biological, clinical and ethical advances. Lancet. 2010; 375 (9715): 686-695. DOI: 10.1016/s0140- 6736 (09) 61706-2.

7. Стрижак О.С., Величко В.Ю., Палагін О.В. та ін. Комп'ютерна програма «Когнітивна IT платформа ПОЛІЕДР (КІТ ПОЛІЕДР)» («POLYHEDRON»). Свідоцтво про реєстрацію авторського права на твір № 96078. 17.02.2020

8. Трансдисциплінарна інтелектуальна інформаційна 
система супроводження процесів реабілітації при пандемії. Колективна монографія /за наук. ред. академіка Палагіна О.В. «Просвіта», 2021. 334c. DOI: 10. 34 229/2707-451x.21. si.1.

9. Иванова Г. Е., Мельникова Е. В. Шаманов Н.А.и др. Использование МКФ и оценочных шкал в медицинской реабилитации. Вестник восстановительной медицины. 2018. №3. C.14-20.

\section{Reference}

1. Zahorodnyi AH, Volkov SV, Onyshchenko OS, Shestopalov VM. V.I.Vernadskyi - vchenyi, myslytel, orhanizator nauky. Visnyk Natsionalnoi akademii nauk Ukrainy. 2013; 32: 8-37. (in Ukrainian).

2. Palagin AV. Informacionno-tekhnologicheskie sredstva upravlyaemoj ehvolyucii. Problemy upravleniya $i$ informatiki. 2021; (5): 104-123. DOI: 10.34 229/10280979-2021-5-9 (in Russian).

3. Palagin AV, Kyrgaev AF, Shevchenko AI. Noosphere Paradigm of the Development of the Science and Artificial Intelligence. Cybernetics and System Analysis. 2017; 5 (53): 503 - 511. Doi: 10.1007/s 10559- 017 - 9952 -

4. Palagin AV. An Introduction to the Class of the
Transdisciplinary Ontology - controlled Research Design Systems. USIM. 2016; (6): 3-15. Doi: 10.15407

5. Palagin AV. Arrangement and functions of a Language world picture in semantical interpretation of natural language messages. Informational theories \& applications. 2000; 7 (4): 155-163.

6. Finnis G, Kaptchuk TJ, Miller F, et al: Placebo effects: biological, clinical and ethical advances. Lancet. 2010; 375 (9715): 686-695. DOI: 10.1016/s0140- 6736 (09) 61706-2.

7. Stryzhak OIe, Velychko VIu, Palahin OV ta in. Kompiuterna prohrama «Kohnityvna IT platforma POLIEDR (KIT POLIEDR)» («POLYHEDRON»). Svidotstvo pro reiestratsiiu avtorskoho prava na tvir № 96078. 17.02.2020 (in Ukrainian).

8. Transdystsyplinarna intelektualna informatsiina systema suprovodzhennia protsesiv reabilitatsii pry pandemii. Kolektyvna monohrafiia pid redaktsiieiu akademika Palahina OV. «Prosvita». 2021; 334p. DOI: 10. 54 521/ ibs34 (in Ukrainian).

9. Ivanova GE, Mel'nikova EV, Shamanov NA, i dr. Ispol'zovanie MKF i ocenochnykh shkal v medicinskoj reabilitacii. Vestnik vosstanovitel'noj mediciny. 2018; (3): 14-20. (in Russian).

\section{THE TRANSDISCIPLINARY SMART INFORMATION-ANALYTIC SUPPORT SYSTEM FOR THE REHABILITATION PROCESSES DURING THE PANDEMIC (TISP)}

\section{Palagin O.V.}

The modern development of information technologies allows us to solve problems of high and the highest difficulty. Their use in a variety of areas related to national security is yielding positive results. Currently, there is an urgent need to support the growth of one of Ukraine's still developing medical fields - Physical Medicine and Rehabilitation Medicine. The Basic Cognitive Information Technology created at the V.M. Glushkov Institute of Cybernetics laid down the basis for the development of the Transdisciplinary Smart Information-Analytic Support System for the rehabilitation processes.

Objective is to develop a Transdisciplinary Smart Information-Analytic Support System for the Rehabilitation Processes during the Pandemic (TISP). The Basic Cognitive Information Technology (BICT) created at the V.M. Glushkov Institute of Cybernetics of the National Academy of Sciences of Ukraine and constantly evolving, was used to develop the TISP. With the help of problem-oriented methods the TISP architecture has been developed, which meets the needs of physical and rehabilitation medicine specialists.

As a result, the information-analytical system was developed as a set of functional subsystems that support all stages of the life cycle from diagnosis to evaluation of the efficiency of the rehabilitation process. The functional content of the system is based on the methodological foundations of recovery and rehabilitation by the recommendations of the White Book on Physical and Rehabilitation Medicine in Europe and the International Classification of Functioning, Disability and Health, which are key European materials. These documents are known to specialists of all ranks: from the medical stuff to the decision-makers at the goverment level in the field of healthcare. And this is quite justified: they are guided by a person in public life, and not by his diseases. For the first time in Ukraine, as a result of intensive interaction of cybernetics and professional physicians-rehabilitologists, the Transdisciplinary Smart InformationAnalytic Support System for the Rehabilitation Processes during the Pandemic has been developed.

Key words: smart cognitive technology, transdisciplinary scientific research, ontological engineering, noosphere theory, experimental design, International classification of functionalities. 